\title{
Relation between erythrocyte selenium concentrations and glutathione peroxidase (EC 1.11.1.9) activities of New Zealand residents and visitors to New Zealand
}

\author{
BY HEATHER M. REA, CHRISTINE D. THOMSON, \\ DIANNE R. CAMPBELL AND MARION F. ROBINSON
}

(Received 20 December 1978 - Accepted 2 May 1979)

\begin{abstract}
I. Erythrocyte, plasma and whole blood selenium concentrations and glutathione peroxidase (EC I. II. 1.9; GSHPX) activities were measured (I) in 104 healthy New Zealand residents living in Otago, a low-soil-Se area (2) in sixty-four surgical patients, including nineteen patients on total parenteral nutrition and twenty-three cancer patients (3) in fifty-two 'overseas subjects' (twenty-five visitors to Otago from outside New Zealand and twenty-seven Otago residents on return from overseas travel).

2. Blood Se concentrations reflected dietary Se intake; means for Otago patients, healthy subjects and overseas subjects were different (0.043, $0.059,0.136 \mu \mathrm{g} \mathrm{Se} / \mathrm{ml}$ blood respectively) and mean for overseas residents was greater than for New Zealand overseas travellers.

3. Erythrocyte Se concentration was always greater than plasma Se, and plasma Se was a smaller proportion of erythrocyte Se for patients compared with the controls.

4. GSHPx activities were different in the three groups, and varied directly with erythrocyte Se until a plateau was reached at approximately $0.14 \mu \mathrm{g} \mathrm{Se} / \mathrm{ml}$ erythrocytes.

5. Overseas subjects showed no relationship between erythrocyte Se and GSHPx activity. This agrees with some overseas studies and the significance of this finding is discussed.

6. Plasma Se concentration remained the most sensitive index of short-term changes in Se status, and erythrocyte Se and GSHPx activities for long-term changes in New Zealand subjects. Use of these measurements for overseas subjects with higher blood levels is discussed.
\end{abstract}

The selenium concentration in whole blood, erythrocytes or plasma has been used until recently as a measure of Se status of animals and human subjects. Since the discovery that Se is an integral part of the enzyme glutathione peroxidase (EC I I I . I .9; GSHPx), the more rapid measurement of enzyme activity has been used as an indicator of blood Se status in animals (Hafeman et al. 1974; Reddy \& Tappel, I974; Hoekstra, 1975), and a simplified technique has been developed for field tests for Se deficiency in sheep (Board \& Peter, 1976). Linear correlations of erythrocyte or whole blood GSHPx activity with blood Se concentrations have been demonstrated for animals (Thompson et al. 1976; Millar, 1977).

Less is known about human Se metabolism but a linear relationship between blood Se and GSHPx activity has been demonstrated for New Zealand residents (Thomson et al. 1977). A similar relationship has been described for some American residents (Rudolph \& Wong, 1978) but not for others (Schrauzer \& White, 1978), and not for some German residents (Schmidt \& Heller, 1976).

This paper reports Se concentrations of patients and healthy residents of Otago (a very low-soil-Se area of New Zealand), visitors to Otago from overseas, and Otago residents returning from visits overseas. Where possible, GSHPx activity has been assayed and Se concentrations measured in erythrocytes and plasma as well as in whole blood. The suitability of using these measurements for evaluating Se status is discussed. 


\section{EXPERIMENTAL}

Subjects

Blood samples were taken from I 68 New Zealand residents; I04 healthy Otago blood donors and sixty-four patients including twenty-three cancer patients (Robinson et al. 1979) and nineteen patients on total parenteral nutrition (TPN) (van Rij et al. 1979). Blood samples were also taken from fifty-two overseas subjects; twenty-five visitors to Otago from overseas, mainly from UK, USA, Australia, Canada and Tahiti, and twenty-seven Otago residents within $\mathrm{I}$ month for most, and always within 2 months, of returning from overseas visits of at least 3 months.

\section{Analytical methods}

Se concentration was determined in whole blood and, where possible, in erythrocytes and plasma by a modification (Griffiths \& Thomson, 1974) of the diaminonaphthalene fluorimetric method of Watkinson (1966).

GSHPx activities were assayed in whole blood by a modification (Thomson et al. 1977; Robinson et al. 1979) of the coupled enzyme assay of Paglia \& Valentine (1967) and expressed as units/g haemoglobin.

\section{RESULTS}

\section{Blood Se concentrations}

Two visitors from Tahiti gave unusually high values of 0.45 and $0.44 \mu \mathrm{g} \mathrm{Se} / \mathrm{ml}$ blood. All other blood Se concentrations varied from $0.015 \mu \mathrm{g} \mathrm{Se} / \mathrm{ml}$ for a patient on TPN to $0.204 \mu \mathrm{g}$ $\mathrm{Se} / \mathrm{ml}$ for a visitor from USA. One of the Tahitians for whom separated samples were available gave a plasma Se of $0.130 \mu \mathrm{g} \mathrm{Se} / \mathrm{ml}$ and erythrocyte Se $0.82 \mu \mathrm{g} \mathrm{Se} / \mathrm{ml}$. The other subjects' plasma ranged from 0.008 to $0.132 \mu \mathrm{g} \mathrm{Se} / \mathrm{ml}$ and erythrocyte Se 0.035 to $0.272 \mu \mathrm{g}$ $\mathrm{Se} / \mathrm{ml}$. The high values for the Tahitians were not included in statistical analysis.

Mean values for patients (Table I) were lower than for healthy blood donors (the controls), and the means for both groups were less than for the combined group of overseas subjects, visitors to New Zealand and New Zealand overseas travellers. Only three of the twentyseven New Zealand travellers were outside New Zealand for less than 6 months; most (fifteen subjects) were away for one year or more. Erythrocyte Se and blood Se for the New Zealand travellers were less than for the overseas visitors $(P<0.00 \mathrm{I})$ whereas plasma Se was only marginally less $(P<0.01)$ and GSHPx activity was not different. Two subjects were followed after their return to New Zealand; during the first 2-3 months plasma Se fell more rapidly than erythrocyte Se and within I year the Se concentrations had returned to the values before travel commenced.

Fig. I shows the relationships between whole blood Se and both erythrocyte Se and plasma Se for the three groups of subjects. Erythrocyte Se was always greater than plasma Se and above $0.16 \mu \mathrm{g} \mathrm{Se} / \mathrm{ml}$ whole blood erythrocyte Se appeared to increase without a corresponding increase in plasma Se. This trend is seen more clearly in Fig. 2, which shows a linear relationship between erythrocyte Se and plasma Se for the control and overseas subjects up to plasma Se of approximately $0.12 \mu \mathrm{g} \mathrm{Se} / \mathrm{ml}$. The inclusion of the results for the Tahitian subjects and from overseas laboratories strengthens the suggestion that an asymptotic curve might be a better fit. On the other hand the straight line for the patients is different but parallel to the controls and overseas subjects, which indicates that concentrations of plasma Se corresponding to those for erythrocyte Se were less for the patients than for the controls. 


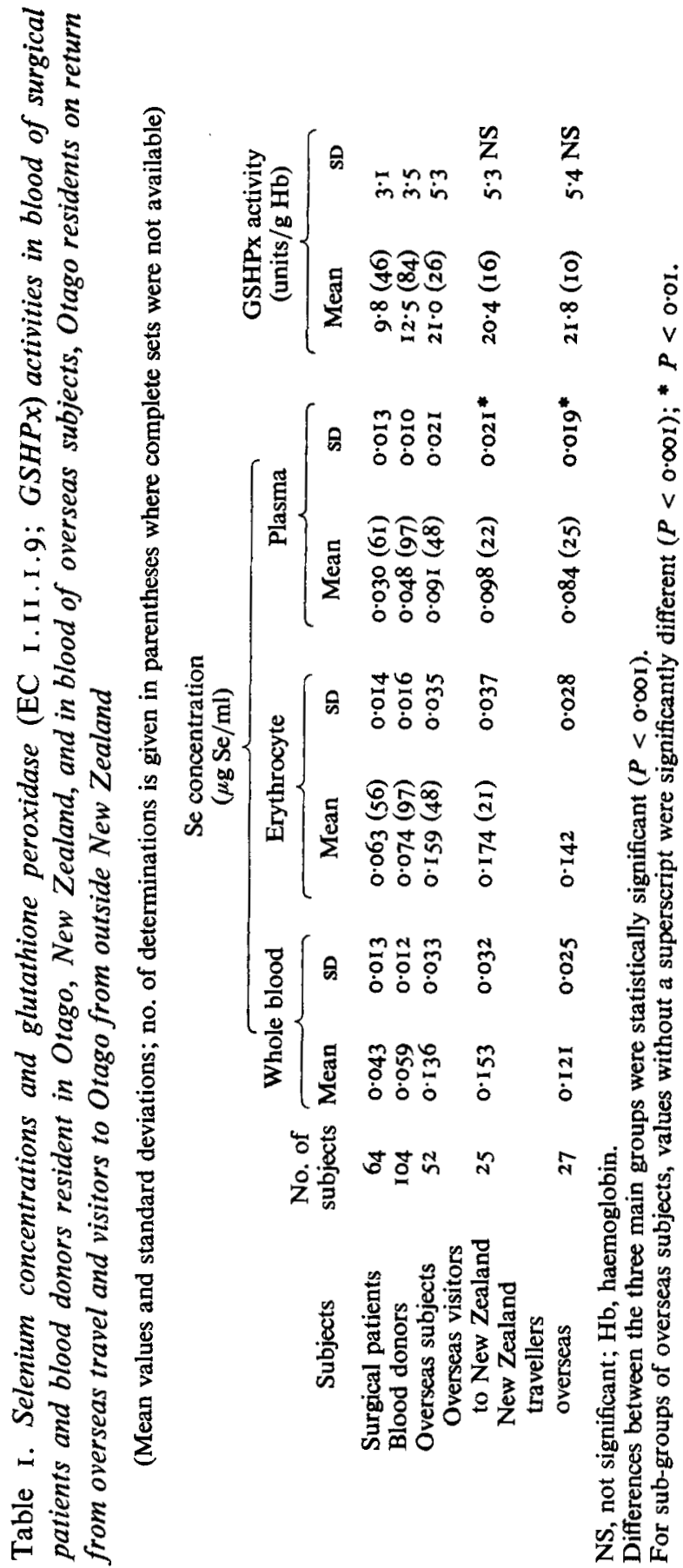




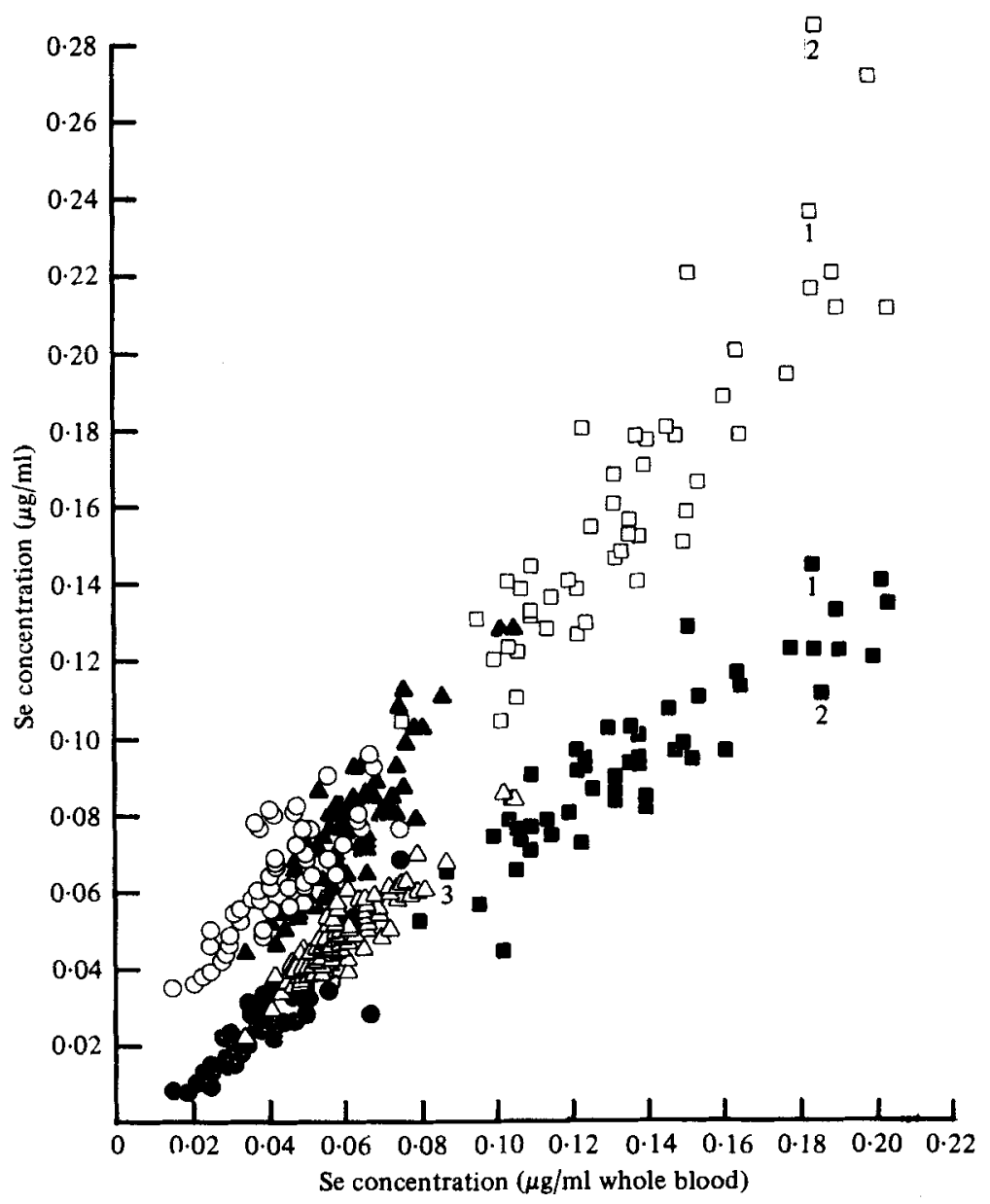

Fig. I. Relationship between selenium concentrations of whole blood and erythrocytes for Otago patients $(O)$, Otago blood donors ( $\Delta$ ) and overseas subjects $(\square)$, and relationship between Se concentrations of whole blood and plasma for Otago patients $(\boldsymbol{\Theta})$, Otago blood donors $(\Delta)$ and overseas subjects $(\boldsymbol{\nabla})$.

Values for overseas residents reported for overseas laboratories: (1), Canada (Dickson \& Tomlinson, I967); (2), Thailand (Levine \& Olson, 1970); (3), Finland (Westermarck et al. 1977).

\section{GSHPx activity and Se concentration}

Fig. 3 shows GSHPx activity in blood varied directly with erythrocyte Se up to $0.14 \mu \mathrm{g} \mathrm{Se} / \mathrm{ml}$ erythrocytes $(P<0.001)$ which happened to be the upper limit of the range for Otago residents. Thereafter enzyme activity reached a plateau with the greater Se concentration in erythrocytes from overseas subjects. The points fitted a quadratic curve.

On the other hand plasma Se $(X)$ and GSHPx activity $(Y)$ in whole blood fitted a straight line $Y$ (units $/ \mathrm{g}$ haemoglobin $)=4 \cdot 4+173 X(\mu \mathrm{g} \mathrm{Se} / \mathrm{ml})$. It so happens that both plasma Se and GSHPx activity seemed to reach a plateau at an erythrocyte Se concentration of approximately $0.14 \mu \mathrm{g} \mathrm{Se} / \mathrm{ml}$. 


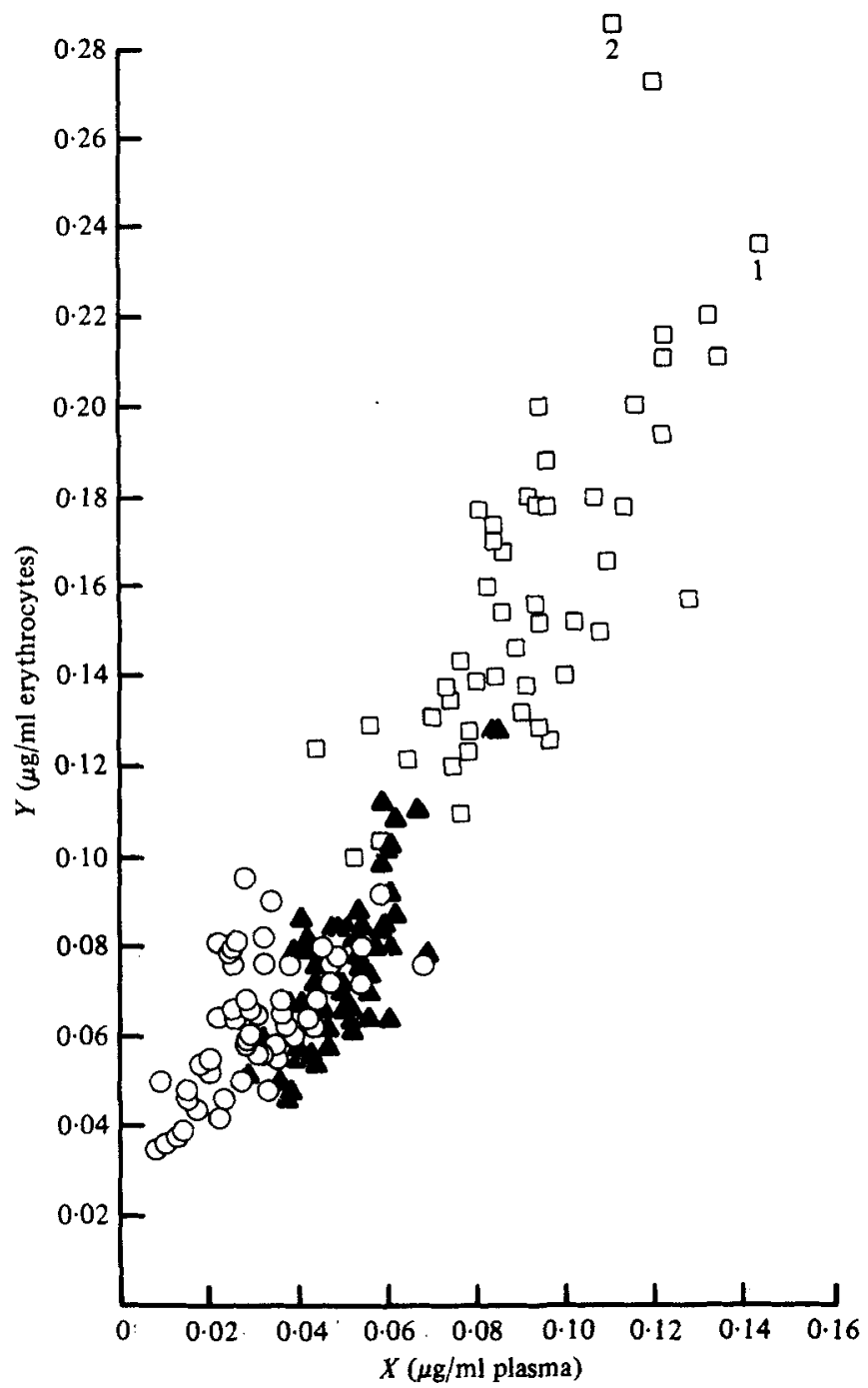

Fig. 2. Relationships between selenium concentrations of plasma $(X ; \mu \mathrm{g} \mathrm{Se} / \mathrm{ml})$ and erythrocyte $(Y$; $\mu \mathrm{g} \mathrm{Se} / \mathrm{ml}$ ) for: Otago patients $(O), Y=0.006+\mathrm{I} \cdot 88 X$; and Otago blood donors $(\boldsymbol{A})$ and overseas subjects $(\square), Y=-0.022+2.00 X$.

Values for overseas residents reported from overseas laboratories: (I), Canada (Dickson \& Tomlinson, 1967); (2), Thailand (Levine \& Olson, 1970).

\section{DISCUSSION}

\section{Blood Se and Se intake}

This study of Otago patients, healthy subjects and travellers, and of overseas visitors to New Zealand provided a unique opportunity for investigating the range between the unusually low blood Se levels in New Zealand and those found in residents in other parts of the world outside New Zealand (Dickson \& Tomlinson, 1967; Levine \& Olson, 1970; Burk, 1976; Schrauzer \& White, 1978; Allaway, 1978). The results from overseas laboratories fitted nicely within the ranges of our overseas values and further demonstrated that blood Se concentrations are lower in New Zealand (Griffiths \& Thomson, 1974; Watkinson, 


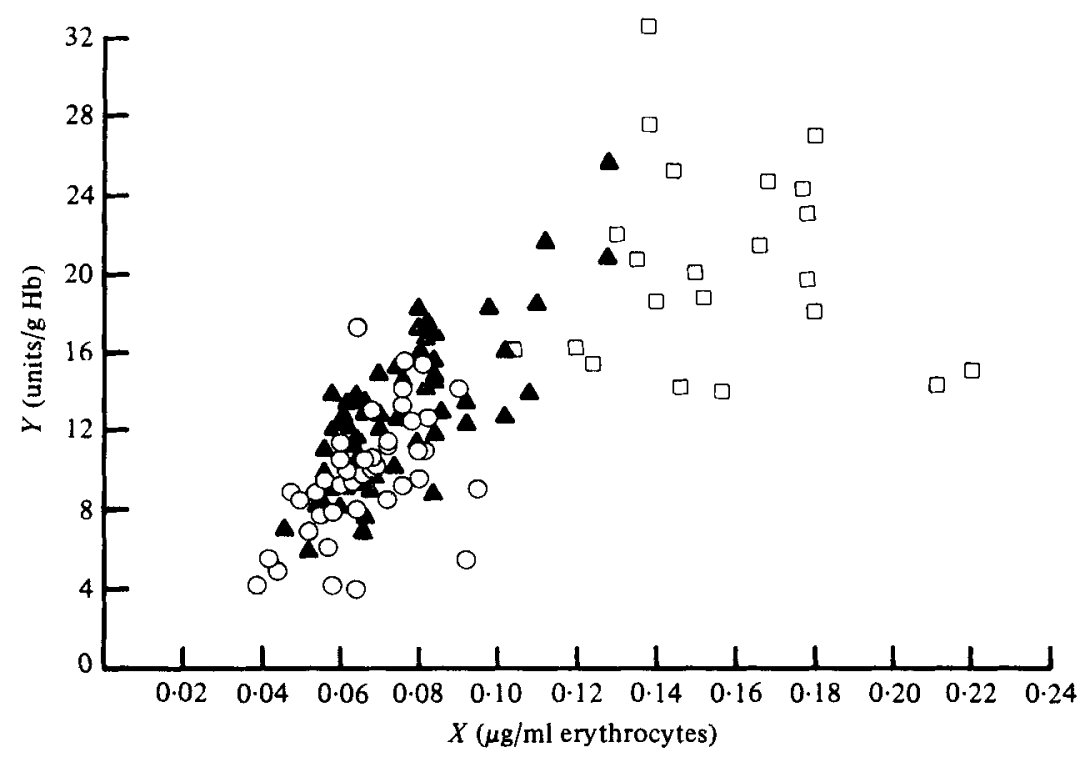

Fig. 3. Relationship between selenium concentration of erythrocytes $(X ; \mu \mathrm{g} \mathrm{Se} / \mathrm{ml})$ and glutathione peroxidase ( $E C$ I.I I.I.9; GSHPx) activity of whole blood ( $Y$; units/g haemoglobin (Hb)) for Otago patients $(O)$; Otago blood donors $(\Delta)$ and overseas subjects $(\square), Y=-7 \cdot 7 \mathrm{I}+358 \mathrm{X}-\mathrm{I} \log X^{2}$.

1974) than anywhere else, except for Finland and some other Scandinavian countries (Westermarck et al. 1977).

New Zealand residents in the present study were exposed to a greater than normal Se intake when travelling outside New Zealand, and to a reduced intake as either TPN patients (van Rij et al. 1979) or as surgical patients with and without cancer (Robinson et al. 1979). Blood Se levels were correspondingly higher or lower. Plasma Se was very low for the patients, being less than half the erythrocyte Se. Moreover plasma Se of New Zealand travellers had approached plasma Se concentrations of the overseas visitors, whereas erythrocyte Se and whole blood Se concentrations were much less. These findings confirm that plasma Se concentration is influenced more readily by changes in Se intake or status than erythrocyte Se concentration (Dickson \& Tomlinson, 1967; van Rij et al. 1979).

\section{GSHPx activity and blood Se}

This study showed again the linear relationship between whole blood GSHPx activity and Se concentrations in New Zealand residents (Thomson et al. 1977). It was proposed in the earlier study that it might be preferable to relate erythrocyte GSHPx activity to erythrocyte Se and indeed a very close relationship was found for four TPN patients (van Rij et al. 1979). However since most of GSHPx activity of the blood is within the erythrocytes and only I-2\% in the plasma (Thomson et al. 1977; Rudolph \& Wong, I978), it was convenient to measure the enzyme activity in this study in the whole blood, and then to relate the activity (expressed in units/g haemoglobin) to erythrocyte Se concentration.

The absence of a linear correlation for the overseas subjects between GSHPx activity and blood or erythrocyte Se concentrations agrees with studies of ten German residents (Schmidt \& Heller, 1976) and some American residents (Schrauzer \& White, 1978), whereas Rudolph \& Wong (1978) found a close correlation for erythrocyte Se concentrations between 
0.20 and $0.65 \mu \mathrm{g} \mathrm{Se} / \mathrm{ml}$ erythrocytes. These studies are not truly comparable with the present study because with few exceptions their blood Se values were greater than those for our overseas subjects. However the tendency for enzyme activity to plateau above $0.14 \mu \mathrm{g} \mathrm{Se} / \mathrm{ml}$ erythrocytes is supported by our findings for the Tahitian visitors whose GSHPx activities were well within the range for our overseas subjects, although their blood Se values were twice as much $(0.45 \mu \mathrm{g} \mathrm{Se} / \mathrm{ml}$ blood).

Schmidt \& Heller (1976) calculated that the enzyme GSHPx accounted for only $10 \%$ erythrocyte Se, and this agrees with their finding of no correlation between enzyme activity and erythrocyte Se concentration. These workers were presumably using the specific activity for bovine enzyme, rather than human enzyme, but it is unlikely that this would be markedly different. The present finding of a close correlation obtained between GSHPx activity and erythrocyte $\mathrm{Se}$ is apparently not in agreement. Thus the regulation of synthesis of $\mathrm{Se}$ dependent GSHPx molecule becomes a most challenging question.

The plateauing of enzyme activity while Se concentration continued to rise could mean that the Se requirement of the enzyme was met and that a dietary intake of Se which maintains this level of enzyme activity represents the human adult requirement, or a recommended intake for Se. Enzyme activities of most New Zealanders were below the plateau, but an apparent Se deficiency has been detected so far in only one New Zealand resident, a TPN patient with extremely low blood values (van Rij et al. 1979).

The meaning of the linear correlation between plasma Se and whole blood GSHPx activity is not clear; but each measurement had reached a plateau at the same stage. Perona et al. (1977) suggested that their close relationship between plasma Se and erythrocyte GSHPx activity indicated Se available for enzyme synthesis, but presumably a similarly close correlation would have been obtained with erythrocyte Se concentrations corresponding to their range of plasma Se concentrations.

\section{Assessment of Se status}

Plasma Se concentration remained the most sensitive index of short-term changes for New Zealand residents and to a limited extent for overseas subjects until the plasma Se reached a plateau. A further indication of current status might be obtained from reticulocyte GSHPx activity and this is being investigated. For a long-term index of Se status, the more rapid measurement of GSHPx activity in whole blood or erythrocytes could replace determinations of erythrocyte $\mathrm{Se}$, but its use is probably restricted to erythrocyte Se concentrations below approximately $0.15 \mu \mathrm{g} \mathrm{Se} / \mathrm{ml}$. The meaning of these blood measurements in terms of total or functional body content of selenium is still not clear, but estimates of whole body Se content for four New Zealand women were in accord with their blood Se concentrations (Stewart et al. 1978).

The authors wish to thank the blood donors and participants for providing blood samples; Ms Gaylene Friend for technical assistance; Mr C. Facer and staff of Otago Blood Transfusion Services; Sister I. J. Whiteford, Dr A. M. van Rij and Dr P. J. Godfrey, Dunedin Hospital for collection of blood samples; Mr G. P. Herbison for his advice and assistance with statistical analysis of results. This study was supported by the Medical Research Council of New Zealand and the New Zealand Medical Research Distribution Committee. 


\section{REFERENCES}

Allaway, W. H. (1978). In Trace Substances in Environmental Health. vol. I 2 [D. D. Hemphill, editor]. Columbia: University of Missouri.

Board, P. G. \& Peter, D. W. (1976). Vet. Rec. 99, I44.

Burk, R. F. (1976). In Proceedings of Symposium on Selenium in the Environment, p. I94. Pittsburgh: Industrial Health Foundation Inc.

Dickson, R. C. \& Tomlinson, R. H. (1967). Clin. chim. Acta 16, 3 I I.

Griffiths, N. M. \& Thomson, C. D. (1974). N.Z. med. J. 80, 199.

Hafeman, D. S., Sunde, R. A. \& Hoekstra, W. G. (I974). J. Nutr. 104, 580.

Hoekstra, W. G. (1975). In Trace Substances in Environmental Health, vol. 9, p. 33I [D. D. Hemphill, editor]. Columbia: University of Missouri.

Levine, R. J. \& Olson, R. E. (1970). Proc. Soc. exp. Biol. Med. 134, 1030.

Millar, K. R. (1977). In Trace Elements in Human and Animal Health in New Zealand, p. 84. Hamilton, New Zealand: Waikato University Press.

Paglia, D. E. \& Valentine, W. N. (I967). J. lab. clin. Med. 7o, I 58.

Perona, G., Cellerino, R., Guidi, G. C., Moschini, G., Stievano, B. M. \& Tregnaghi, C. (1977). Scand. J. Haematol. 19, II 6.

Reddy, K. \& Tappel, A. L. (1974). J. Nutr. r04, 1069.

Robinson, M. F., Godfrey, P. J., Thomson, C. D., Rea, H. M. \& van Rij, A. M. (1979). Am. J. clin. Nutr. (In the Press).

Rudolph, N. \& Wong, S. L. (1978). Pediat. Res. 12, 789.

Schmidt, K. \& Heller W. (1976). Blut 33, 247.

Schrauzer, G. N. \& White, D. A. (1978). Bioinorganic Chem. 8, 303.

Stewart, R. D. H., Griffiths, N. M., Thomson, C. D. \& Robinson, M. F. (1978), Br. J. Nutr. 40, 45.

Thompson, R. H., McMurray, C. H. \& Blanchflower W. J. (1976). Res. vet. Sci. 20229.

Thomson, C. D., Rea, H. M., Doesburg, V. M. \& Robinson, M. F. (I977). Br. J. Nutr. $37,457$.

van Rij, A. M., Thomson, C. D., McKenzie, J. M. \& Robinson, M. F. (I979). Am. J. clin. Nutr. (In the Press).

Watkinson, J. H. (1966). Analyt. Chem. 32, 981.

Watkinson, J. H. (1974). N.Z. med. J. 80, 202.

Westermarck, T., Raunu, P., Kirjarinta, M. \& Lappalainen, L. (1977). Acta pharmac. tox. 40, 1977. 